\title{
Grass Roots and Deep Holes: Community \\ Responses to Mining in Melanesia
}

Colin Filer and Martha Macintyre

\section{The Regional Configuration}

Imagine that a group of experts had been brought together in 1985 to discuss how the mining sector could contribute to sustainable development in Melanesia. It is exceedingly unlikely that anyone at the meeting would have forecast the outbreak of the Bougainville rebellion in 1988 and the forced closure of the Panguna copper mine in 1989. It is quite unlikely that anyone would have foreseen the internationalization of debate about the environmental impact of the Ok Tedi mine, let alone the Australian litigation against Broken Hill Propriety Limited (BHP) as the mine's operator (Banks and Ballard 1997). Instead, the Papua New Guinea contingent at the meeting would probably have been congratulating themselves for having a mineral policy framework that was the envy of other developing countries. They would have cited the mineral exploration boom of the mid-I980s as proof that they were on the right track; and they would probably have cited Bougainville Copper Limited's training and localization program and Ok Tedi Mining Limited's environmental monitoring program as examples of industry best practice. Policy makers from around the region would have nodded in agreement and undertaken to emulate this shining example.

The articles in this issue are restricted to the Independent State of Papua New Guinea and the French Territory of New Caledonia, so we need to take some care in generalizing from these two cases to the political, social, and cultural significance of mining in "Melanesia." The Vatukoula gold mine in Fiji, which has been operating for several decades, makes a very small contribution to the national economy (only 2 percent of gross 
domestic product), and most of the literature that deals with the social and cultural dimensions of mining in Fiji is concerned with the history of colonial and postcolonial labor relations in this one mine (Emberson-Bain I994). The Gold Ridge mine in Solomon Islands, similar in scale to Vatukoula but potentially more significant for the country's economy, was only operational for a couple of years before it closed due to political unrest. It has not yet attracted much attention from social scientists. However, there is no reason to assume that Fijians and Solomon Islanders will think about the prospect of mining in the same way as those Papua New Guineans who know a lot about it but have little direct experience of it, because mining dominates the news in Papua New Guinea in a way that it has yet to do in the Solomons and has hardly ever done in Fiji. As the essays in this collection illustrate, in the minds of most Papua New Guinean "grassroots" or village people, mining has become the way to gain wealth rapidly and to ensure that dreams of "development" and "modernity" come true. In New Caledonia, where mining has long been the main primary industry, people's responses are tempered by long experience of colonial relations in the mining sector, and these Melanesians are undoubtedly more cautious about the transformative effects of mining projects on their territory (Horowitz 2003). Since most of the articles deal with Papua New Guinea, and in order to contextualize the grassroots social and cultural constructions of mining as a source of wealth, it is necessary to look first more broadly at the recent history of mining in that nation.

\section{Aspects of Resource Dependency}

In the twenty years following the opening of the Ok Tedi mine in 1982, four large-scale mining projects (Ok Tedi, Misima, Porgera, and Lihir) generated a national benefit, the monetary value of which has been estimated (in real terms) at 6.4 billion kina per annum-currently worth about Us $\$ 2$ billion. From this amount, the PNG national government received 4.I billion kina in duties, taxes, and royalties, while national employees received I.9 billion kina in wages, superannuation, and educational costs, and 400 million kina was received directly by institutions or landowners from the host provinces in the form of compensation, donations, and community assistance. The national government returned 26 percent of its own share to the host provinces in the form of royalties, "special support grants," other mining grants, the tax credit scheme, and dividends on project equity. In addition, under the terms of the govern- 
ment's "preferred area policy," workers from the host provinces received 28 percent of the benefits obtained by national employees. So the net result was that people and institutions in the four host provinces received 32 percent of the total national benefit stream, while the remainder was divided among the rest of the national population or allocated through the national budget (Finlayson 2002). ${ }^{1}$

Mining companies account for roughly 6 percent of Papua New Guinea's formal sector employment, but major resource projects create additional employment in both the formal and informal sectors. For example, Ok Tedi Mining Limited employs about 2,000 people, but another 3,500 are employed in the supply of goods and services to the mining company, and an unknown number derive part of their income from the supply of goods and services to all these employees (Baxter 200I). When the Panguna mine was operating, Bougainville Copper Limited was recognized as a global industry leader because of its training and localization program, and this investment in human capital has continued to benefit the national economy to the present day.

The economic benefits of a dominant extractive industry sector are offset by a range of economic, social, political, and environmental risks and costs that are grouped together by the concept of a "resource curse." The resource curse is often portrayed as a purely economic phenomenon, in which the excessive dependence of a national or regional economy on the mining or petroleum sectors (or both) has a variety of negative effects on other sectors of the economy (Auty 199I). However, the negative effects of a dominant or booming extractive industry sector can also be portrayed in political, cultural, or environmental terms, which means that the resource curse may have several dimensions within the same country or region:

- In political terms, the curse involves an intensification of conflict between actors on the national (or even the international) stage who are competing with each other for access to the resource rents generated by this kind of industry (Chand and Levantis 2000; Banks 2005; Ali and Grewal, and Golub this issue).

- In cultural terms, the curse involves the development of unrealistic hopes and expectations, by people who do not presently derive any benefits from this kind of industry, that new discoveries will put them on a par with those who do (Stürzenhofecker 1994; Guddemi I997; Halvaksz, Jorgensen, and West, this issue). 
- In environmental terms, the curse involves a degree of long-term damage done to the natural environment, which outweighs the short-term economic benefits obtained by a minority of the affected population (Hyndman 1994; Kirsch 200I).

These problems are compounded by the fact that resource development enclaves tend to be isolated from the other parts of a country's economy and society for the limited period of time that is normally required for the extraction of a nonrenewable resource.

One of the by-products of the Bougainville rebellion was a much higher level of political and academic interest in the social (as well as the environmental) impact of large-scale mining operations in Papua New Guinea and other parts of Melanesia. The social impact debate has focused on the unequal distribution and wasteful consumption of mine-related benefits in mine-affected communities, with particular emphasis on intergenerational conflict (Filer 1990; Macintyre and Foale 2004; Golub, Jorgensen, and West, this issue); the marginalization of women (Bonnell 1999; Macintyre I993, 2002, 2003, 2004); and the size of compensation packages (Connell I99I; Banks I996; Filer and others 2000).

Papua New Guinea is the only country from the Pacific Islands region to have featured extensively in recent international debates about the actual or potential contribution of the mining industry to the elusive goal of "sustainable development." Although the Bougainville and Ok Tedi mines were held up as examples of bad policy or practice in the final report of the Mining, Minerals and Sustainable Development Project (MMSD 2002), the news has not all been bad. The same report featured Papua New Guinea's “development forum” as a model process for the negotiation of integrated benefit packages involving local communities and different levels of government (West I992; Filer 2005). So Papua New Guinea now has a global reputation in extractive industry circles as a country in which some very hard lessons have been learned.

The findings of the MMSD project played an important part in framing the set of issues canvassed in a green paper produced by the Papua New Guinea Department of Mining at the beginning of 2003 (PNGDOM 2003). This attempt to establish a "sustainable development policy and sustainability planning framework" for the mining sector was one component of an institutional strengthening project funded by the World Bank. The project, which is currently nearing completion, arose out of a concern on the part of the World Bank and some policy makers in Papua New 
Guinea that an observed decline in the levels of new investment in the mining sector could have very serious economic and political effects within the next decade.

However, the Papua New Guinea experience over the last few years suggests that implementation of the best policy package for the mining sector is seriously constrained by a diminishing capacity for effective collaboration between different government agencies and the existence of powerful vested interests within the political system (Burton I998; Simpson 2002). This means that it is very difficult to secure a broad consensus about the equitable distribution of mineral wealth or the dissemination of information about the way that wealth is actually distributed once it has left the hands of the companies that produce it. These variations at the highest level are further complicated by the pervasive view at the popular, grassroots level that benefits from mining should be local rather than national. The cultural foundations for localized understandings of mining - in particular, the ways that communities perceive their rights to land and resources-provide the basis for many of the articles in this collection.

The length of Papua New Guinea's experience of engagement with the mining industry is significant because the PNG government has a long record of producing new policies to regulate it, even if the government has become increasingly dependent on support from the private sector or the donor community to make those policies effective (Filer and Imbun 2004). The small island states of the Pacific have generally been inclined to fashion their own policies in light of the lessons learned from Papua New Guinea (Filer 200I), even though Fiji's major mining operation is much older than any of the current major mining operations in Papua New Guinea.

The government of Solomon Islands, in particular, has been painfully aware of the need to learn lessons from the Bougainville experience and from the way in which the Papua New Guinea government has tried to avoid any repetition of that disaster. Yet we must also remember that the Gold Ridge mine, when it resumes operations, will be no bigger than the smallest of the four major mining operations currently underway in Papua New Guinea, but contributes as much to the Solomon Islands economy as the whole of the mining and petroleum sectors contribute to the Papua New Guinea economy. Since the size of a mineral deposit tends to determine the lifespan of a mining operation, Solomon Islands is far more vulnerable to the economic and political shocks of opening and closing one 
medium-scale mining operation that only lasts for a few years, while Papua New Guinea was able to cope with the closure of the Bougainville mine because other major resource projects came onstream around the same time.

\section{Local Contexts and Responses}

This collection of essays illustrates the range and diversity of Melanesian responses to mining projects in both space and time. Two of the large-scale mines that are currently operating-Ok Tedi and Porgera-are located in the mountainous interior of the mainland; like the Panguna mine before them, both are engaged in the widely criticized practice of riverine tailings disposal. The other two large-scale mines developed in recent years-Misima and Lihir-have been constructed on small offshore islands and have piped their tailings down to the floor of the ocean. The differences in their geographical locations and methods of waste disposal have entailed a substantial difference in the number of landowning communities whose members could be regarded as "stakeholders" in each of these projects, and also in the variety of "stakes" that each of them holds. In the case of Misima and Lihir, the development of a large-scale mine has created a new sense of islandwide social identity, even if the "community" that is thus set apart from the rest of the nation is also divided by the unequal distribution of benefits derived from the mine in its midst (Gerritsen and Macintyre 199I). In the case of Ok Tedi and Porgera, there are many more communities, upstream and downstream of the mine, whose members experience different degrees of social and environmental impact, or have different amounts of power to disrupt mining operations if they are not satisfied with the benefits they receive.

Once the regional diversity of Melanesian culture is overlaid on this variety of geographical circumstance, it becomes quite difficult to make general statements about the quality of relationships between landowning communities and the other stakeholders engaged in the large-scale mining industry (Filer I998).

From one point of view, mining companies have been trampling on the rights and livelihood of indigenous peoples with the connivance of a government that is too corrupt or greedy to protect them (Hyndman I99I). From another point of view, the government has been unable to manage the expectations and demands of local landowners to an extent that pre- 
vents them from taking their frustrations out on the mining companies that are squatting on their land (Jackson 199I). From a third point of view, it is very difficult for anyone-whether it be a mining company, a government agency, or even a customary landowner-to do business on customary land, because property rights in customary land are not properly defined in law (Ballard I997).

The stages in any large mining project extend from exploration to construction and production through to closure. The sequence of mining itself ensures that attitudes within communities vary as expectations alter over the duration of a project, and, as the Wau and Bougainville cases show, in retrospect. While there have been varied reactions from local people, these essays reveal that there are also many similarities and consistencies as people see mining as their road to "development" and modernity. Resource extraction-mining, logging, and fishing-are industries that continue to be dominated by foreigners, but they provide people with the means of entering the cash economy and participating in development at many levels.

International nongovernmental organizations have tended to emphasize the negative impacts of mining, especially on indigenous communities and their environments (Macdonald 2004a; 2004b). The anthropological studies presented here challenge notions of unified interest or consensus at the local level, revealing ambivalence and contradictions. They show that understandings of mining and its social consequences are always inflected by the cultural conceptions of change, wealth, and resources that obtain in a community. On balance, the articles in this special issue testify to the enthusiasm with which Melanesians welcome mining on their land. Those whose experience is limited to rumor and exploration, such as the Maimafu, hope that a gold mine will be established but are wary of some of its social and environmental consequences (West, this issue). Those who are host to a mine in production, such as the Ipili at Porgera, seize the benefits that accrue to them with alacrity and are generally happy to have "traded their mountain for development" (Golub, this issue, 288). The Telefolmin, whose peripheral relationship to the Ok Tedi mine enabled them to gain some benefits, fear the effects of closure and respond by restructuring their cultic beliefs around the idea of a mine in the future, where they will be the landowners and their land the site of a flourishing township (Jorgensen, this issue). And the Biangai harbor nostalgia for the distant times when Wau was a "boom town" and they briefly glimpsed 
the delights of modern urban life, with "a movie theater, a swimming pool, telephones, stores, a brewery, tennis courts, a rifle range, motor vehicles, a Masonic temple, a hotel, and regular air service" (Halvaksz, this issue, 346).

\section{The Melanesian Workforce}

Historically, Melanesian people engaged in any mining enterprise mostly as unskilled laborers. Both Benedict Y Imbun and Jamon Halvaksz recount the ways that Papua New Guineans were employed as indentured laborers in the early gold mining era and the divisive effects of this system. Men from coastal areas went to work in regions where they were strangers, and their presence was often resented. Today the influx of migrant labor from the hinterland of large projects such Porgera and Ok Tedi generates considerable tensions along "tribal" or "ethnic" lines as people resent others getting jobs that they think should be given to local people. But as Imbun explains, many landowners are ambivalent about being wage laborers, preferring to own businesses that have contracts with the mining company. Even those who do work for wages often see their employment as temporary-a means of saving for some independent enterprise. The policies of "nationalizing" the workforce have ensured that in all mines now operating the vast majority of employees, skilled and unskilled, are Papua New Guinean. While boards of directors and chief executive officer positions continue to be dominated by white expatriates, and much of the profits go to foreign shareholders, the face of mining at head office, on the ground, and in the pit, is now decidedly Melanesian. The case of Ila Temu, recently appointed as country manager of Placer Dome's operations in Tanzania, illustrates the fact that Melanesians now occupy senior management positions in the mining industry, not only in their countries of origin, but also in foreign parts. Ila will be the fifth Papua New Guinean to be posted to Tanzania by Placer Dome because of his particular expertise (PNG Post-Courier 2005a), and there are a number of highly qualified Papua New Guineans now employed in the mines of Australia, many in technical areas.

\section{VISIONS OF IMPACT}

In the early stages of negotiating lease agreements in Papua New Guinea, mining companies take pains to emphasize the advantages that mining will bring-in employment, infrastructure, services, and standards of liv- 
ing. Several mining companies have taken groups of villagers to see other mine sites to ensure that they understand the nature of the changes that will occur on their land if they consent to the mining lease. People from Misima were flown to Kidston in Australia by Placer Pacific to see the open pit there in 1986 before the Misima mining agreement was signed; landowners from Lihir in New Ireland Province visited Bougainville in I988, where they encountered Francis Ona, leader of the Bougainville Revolutionary Army, just before the outbreak of armed conflict. While mining company managers hoped that such visits would ensure that local people had a clear understanding of the nature and extent of the physical changes to be inflicted on their environment-particularly the size of the hole in the ground-visitors tended to notice the material advantages that people enjoyed. They observed the roads and motor vehicles, the houses of milled timber with metal roofs, the schools and hospitals and the accoutrements of modernity such as smart clothing, wristwatches, and electrical appliances that they have long believed signal "development." Paige West's account of the Maimafu tour of the mine at Porgera in 200 I confirms the attraction of these changes for the visitors. But unlike Misimans and Lihirians, the Maimafu also noticed the land clearing and environmental degradation, and the large numbers of people who were "locked out," whose lives appeared diminished by the advent of the mine. Their previous exposure to conservationist ideologies during the period when the Integrated Conservation and Development Project was established at Crater Mountain tempered the attractions of modernity at the cost of social and economic inequalities and loss of land.

But while the men from Maimafu weigh up the benefits of mining and observe "the contradictions of capitalism," for a majority of Papua New Guinean villagers the desire for development sweeps aside contemplation of its negative effects-even when these have been directly experienced. The Bougainville and Ok Tedi projects both involved environmental damage that severely affected rivers, compromised subsistence activities, and resulted in massive claims for compensation, yet by 2002 the Yonggom living south of the Ok Tedi mine, whose river and land had been silted and flooded, had decided that it was in their best interests for mining to continue because their claims might otherwise be ignored (Kirsch 2002). For the Telefol people to the north, the environmental damage along the Ok Tedi River in no way dented their enthusiasm for mining and modernity because they did not have to live with the consequences. As the mine approaches closure, they not only called for geologists to explore their territory but also began excavating their own large hole in the ground in 
the hope of discovering gold. More recently, the Papua New Guinea minister for mining, Mr Sam Akoitai, reprimanded members of the Autonomous Bougainville Government, who had invited representatives from Australian and Canadian mining companies to negotiate exploration for new projects there despite a long-standing national government moratorium on mineral exploration (PNG Post-Courier 2005b). For the many Bougainvilleans who fought a civil war over the large hole in the ground at Panguna, and their international supporters who deplored the environmental destruction it caused, this rapid about-face on mining demands explanation. The essays here on Papua New Guinea reveal the ways that mining, in spite of the problems it generates, appears to be a sure way that local people can gain employment, business opportunities, roads, hospitals, and schools - the development that their government has been unable to deliver. While the reality might not conform to the myth-dreams of those who hope that their land will be the site for the next mine, there is sufficient evidence of relative wealth and advantage to feed aspiration among those who have no mine and nostalgia among those whose mine has closed.

\section{The Colonial Legacy}

Saleem H Ali and Andrew Singh Grewal's article in this collection demonstrates that the view from New Caledonia, where nickel mining by French and foreign companies has long been essential to the economy, is somewhat different. Resistance to a proposed mining project at Goro near Nouméa has grown and drawn in support from international environmentalist and human rights organizations. Opposition is framed mainly in terms of predicted environmental damage, but as the authors illustrate, local people are especially hostile because of the lack of transparency, flexibility, and indigenous ownership. The companies involved in the Koniambo project in the country's Northern Province, by contrast, have been "praised by environmentalists for their openness in communicating the details and environmental impacts of the development to the public, exemplified by their thorough environmental study" (Ali and Grewal, this issue, 382). Closer scrutiny of their argument suggests that the Kanaks in New Caledonia do share the views of the Melanesians in Papua New Guinea on many issues; major factors in their support for Koniambo are the recognition of the rights of the local people and the fact that the wealth generated will remain in the territory. As the authors observe, recognition 
of their "sovereignty" is of great symbolic significance for the Kanaks, and economic gains for local communities reinforce Kanak support for Koniambo.

We should therefore not rush to assume that indigenous opposition to large-scale mining in Melanesia is a simple function of political subordination to a colonial or external power that is seen to support it, even if that appears to be the lesson of what happened on Bougainville during the final years of Australian rule (Filer I998; Denoon 2000).

\section{Myths AND DReams}

Several of the contributors to this issue examine the ways that traditional worldviews, beliefs, and myths are adapted, transformed, and interwoven with contemporary ideas about development and mining (see also Weiner and Rumsey 200I). These myths are in some ways the projection of very material desires that are expressed through dreams, prophecies, and visions. In many respects they can be interpreted also as ways of legitimizing their claims to be the "landowners" of any future mine (Jorgensen I997). Many imagine that "development," in the form of a large mine on their land, will change their lives, bringing them the services, employment, and wealth that the government has failed to deliver.

The mythic dimensions of mining wealth and their force in the Melanesian imaginary are themes that recur in these essays. Gold, and more recently "diamonds" (although there are no diamond mines in Papua New Guinea), and even "diamond gold" have become magical substances that are linked to origins of wealth and power in the past, just as they become the means of making money in the present. Paige West introduces her discussion of the ways that the Maimafu perceive the "development" choices offered to them by mining and conservation projects with an account of a vision of a "golden man" who strides across the landscape, stopping finally at the disputed land of the proposed mine. She demonstrates that Maimafu have ambivalent responses to the inequalities that accompany mining projects, which originate in their encounters with another discourse of modernity - that of environmental conservation. The desire to establish social ties with those who will then bring them the material wealth and services reflects a distinctly Melanesian approach to the processes of change and the acquisition of goods that emphasizes the establishment of social relationships with those whom they hope will "provide access to goods and services and help to bridge spatial, social, and ideo- 
logical divisions" (3IO). Dan Jorgensen's discussion of Telefol responses to the impending closure of the Ok Tedi mine demonstrates clearly that the experience of marginality in one project in no way dampens enthusiasm for mining. Their disappointment at not having been able to claim ownership of the gold at Mt Fubilan has transmuted into a conviction that "gold and diamonds" will be discovered on their own land so that a new mine might be developed. Jorgensen argues that old myths have been reinterpreted not only to account for their marginality in the Ok Tedi project but also to ensure their centrality in an imagined future that promises even greater wealth. The myths also provide a way of constructing fantasies of a future in which the village will become a city, the hard work of growing food will be replaced by shopping in a supermarket, and their bush-material houses will be replaced by houses of timber and iron.

The visions of future prosperity harbored by those who do not have a mine often center on the legendary luxuries and leisure that "landowners" acquire when they get their compensation or royalty checks. The state regulation of mining and the requirements that companies negotiate agreements with customary landowners ensures that those identified as "landowners" gain large sums of money as compensation and royalties. As Golub shows for the Ipili, the prize in any project is to be among those who are able to become rich on what is essentially rent for their land (see also Filer 1997). They can head for the bright lights of hotels in the city and drink beer all day without even having to labor for their money.

Twenty years ago, our hypothetical meeting of experts would have operated with a view of sustainability that was far more restricted in scope. They, like the national governments of Melanesian countries, would have concentrated on the economic blessings anticipated to flow from a flourishing minerals industry and the ways that the wealth generated could be used by the state to fund further development. The emerging conflicts between the various actors on Bougainville and the competition over resource rents were not perceived as threats to mining operations. The lengthy feasibility and environmental impact studies that preceded Ok Tedi and Misima suggested that environmental impacts would be managed carefully and that the curse of long-term environmental damage could be avoided. The social and cultural studies of the small communities who then lived in areas where mining projects were beginning noted that expectations were unrealistically high and that the prospect of employment would attract people to the region, but could not have predicted the extraordinary population growth due to in-migration that sub- 
sequently occurred around the Porgera and Ok Tedi mines. The embrace of modernity, the welcoming of the material benefits that came with economic development and the engagement of affected communities also appeared to be blessings that could ensure that the development enterprise was sustainable. But as the contributors to this issue demonstrate, the complex cultural understandings of mining, development, and control over land and resources challenge simple interpretations of the relationship between "tradition" and modernity. The promise that wealth generated by mining would strengthen the state and increase its capacity to improve services across the nation was not fulfilled. The intervening years have ensured also that competing interests are manifest as political divisions that jeopardize sustainability. The political, environmental, and cultural manifestations of the "resource curse" have emerged over two decades in varying degrees and in different locations across the region. The contributors to this issue concentrate on the ways that different communities-people at the grassroots level-construct their interests and attempt to manage their engagement with others to ensure that they reap the benefits of development.

\section{Note}

I These calculations do not take any account of the benefit streams derived from the Panguna copper mine before its closure in I989, nor those derived from small- and medium-scale mining operations.

\section{References}

Auty, Richard

I99I Managing Mineral Dependence: Papua New Guinea 1972-89. Natural Resources Forum I 5 (2): 90-IOI.

Ballard, Chris

I997 It's the Land, Stupid! The Moral Economy of Resource Ownership in Papua New Guinea. In The Governance of Common Property in the Pacific Region, edited by Peter Larmour, 47-65. Pacific Policy Paper I9. Canberra: Australian National University, National Centre for Banks, Glenn Development Studies.

I996 Compensation for Mining: Benefit or Time-Bomb? The Porgera Gold Mine. In Resources, Nations and Indigenous Peoples: Case Studies 
from Australasia, Melanesia and Southeast Asia, edited by Richard Howitt, John Connell, and Philip Hirsch, 223-235. Melbourne: Oxford University Press.

2005 Linking Resources and Conflict the Melanesian Way. Pacific Economic Bulletin 20 (I): I 85-I9I.

Banks, Glenn, and Chris Ballard, editors

1997 The Ok Tedi Settlement: Issues, Outcomes and Implications. Pacific Policy Paper 27. Canberra: Australian National University, National Centre for Development Studies.

Baxter, Michael

200I Enclaves or Equity: The Rural Crisis and Development Choice in Papua New Guinea. International Development Issues 54. Canberra: AusAID.

Bonnell, Susanne

I999 Social Change in the Porgera Valley. In Dilemmas of Development: The Social and Economic Impact of the Porgera Gold Mine, I9891994, edited by Colin Filer, 19-87. Pacific Policy Paper 34. Canberra: Asia-Pacific Press.

Burton, John

I998 Mining and Maladministration in Papua New Guinea. In Governance and Reform in the South Pacific, edited by Peter Larmour, I 54-I82. Pacific Policy Paper 23. Canberra: Australian National University, National Centre for Development Studies.

Chand, Satish, and Theo Levantis

2000 Dutch Disease and the Crime Epidemic: An Investigation of the Mineral Boom in Papua New Guinea. Agricultural and Resource Economics 44 (I): I $29-\mathrm{I} 46$.

Connell, John

I99I Compensation and Conflict: The Bougainville Copper Mine, Papua New Guinea. In Connell and Howitt I991, 54-75.

Connell, John, and Richard Howitt, editors

I99I Mining and Indigenous Peoples in Australasia. Sydney: Sydney University Press.

Denoon, Donald

2000 Getting under the Skin: The Bougainville Copper Agreement and the Creation of the Panguna Mine. Melbourne: Melbourne University Press.

Emberson-Bain, Atu

I994 Labour and Gold in Fiji. Cambridge: Cambridge University Press.

Filer, Colin

I990 The Bougainville Rebellion, the Mining Industry and the Process of Social Disintegration in Papua New Guinea. Canberra Anthropology I3 (I): I-39. 
I997 Resource Rents: Distribution and Sustainability. In Papua New Guinea: A 20/20 Vision, edited by Ila Temu, 220-260. Pacific Policy Paper 20. Canberra: Australian National University, National Centre for Development Studies.

I998 The Melanesian Way of Menacing the Mining Industry. In Modern Papua New Guinea, edited by Laura Zimmer-Tamakoshi, I47-I77. Kirksville, mo: Thomas Jefferson University Press.

200I Between a Rock and a Hard Place: Mining Projects, "Indigenous Communities," and Melanesian States. In Mining in Papua New Guinea: Analysis and Policy Implications, edited by Benedict Imbun and Paul McGavin, 7-24. Waigani: University of Papua New Guinea Press.

2005 The Role of Land-Owning Communities in Papua New Guinea's Mineral Policy Framework. In International and Comparative Mineral Law and Policy: Trends and Prospects, edited by Elizabeth Bastida, Thomas W Wälde, and Janeth Warden-Fernández, 903-932. The Hague: Kluwer Law International.

Filer, Colin, David Henton, and Richard Jackson

2000 Landowner Compensation in Papua New Guinea's Mining and Petroleum Sectors. Port Moresby: PNG Chamber of Mines and Petroleum.

Filer, Colin, and Benedict Imbun

2004 A Short History of Mineral Development Policies in Papua New Guinea. RMAP Working Paper 55. Canberra: Australian National University, Research School of Pacific and Asian Studies, Resource Management in Asia-Pacific Program.

Finlayson, Michael

2002 Sustainable Development Policy and Sustainability Planning Framework for the Mining Sector in Papua New Guinea. Working Paper 2: Benefit Stream Analysis. Port Moresby: PNG Mining Sector Institutional Strengthening Project.

Gerritsen, Rolf, and Martha Macintyre

I99I Dilemmas of Distribution: The Misima Gold Mine, Papua New Guinea. In Connell and Howitt r991, 34-53.

Guddemi, Philip

I997 Continuities, Contexts, Complexities, and Transformations: Local Land Concepts of a Sepik People Affected by Mining Exploration. Anthropological Forum 7 (4): 629-648.

Horowitz, Leah

2003 Stranger in One's Own Home: A Micropolitical Ecological Analysis of the Engagements of Kanak Villagers with a Multinational Mining Project in New Caledonia. PhD thesis, Australian National University.

Hyndman, David

I99I Zipping Down the Fly on the Ok Tedi Project. In Connell and Howitt I99I, 76-90. 
I994 Ancestral Rain Forests and the Mountain of Gold: Indigenous Peoples and Mining in New Guinea. Boulder, CO: Westview Press.

Jackson, Richard

I99I Not without Influence: Villages, Mining Companies and Government in Papua New Guinea. In Connell and Howitt I991, I8-33.

Jorgensen, Dan

I997 Who or What Is a Landowner? Mythology and Marking the Ground in a Papua New Guinea Mining Project. Anthropological Forum 7 (4): 599-627.

Kirsch, Stuart

200I Changing Views of Place and Time Along the Ok Tedi. In Weiner and Rumsey 200I, 243-272. Bathurst, NSw: Crawford House Press.

2002 Anthropology and Advocacy: A Case Study of the Campaign against the Ok Tedi Mine. Critique of Anthropology 22 (2): I75-200.

Macdonald, Ingrid

2004a Mining Ombudsman Case Report: Tolukuma Gold Mine. Fitzroy, vic: Oxfam Community Aid Abroad.

2004b Mining Ombudsman Case Report: Vatukoula Gold Mine. Fitzroy, vic: Oxfam Community Aid Abroad.

Macintyre, Martha

I993 Women and Mining. In Papua New Guinea and Australia: Towards 2000, 43-49. Fitzroy, VIC: Community Aid Abroad/Freedom from Hunger.

2002 Women and Mining Projects in Papua New Guinea: Problems of Consultation, Representation and Women's Rights. In Tunnel Vision: Women, Mining and Communities, edited by Ingrid Macdonald and Claire Rowland, 26-29. Melbourne: Oxfam-Community Aid Abroad.

2003 Petztorme Women: Responding to Change in Lihir, Papua New Guinea. Oceania 74 (I/2): I 20-I34.

2004 Thoroughly Modern Mothers: Maternal Aspirations and Declining Mortality on the Lihir Islands, Papua New Guinea. Health Sociology Review: International Journal of Health Sociology: Policy, Promotion and Practice I3 (I): 43-53.

Macintyre, Martha, and Simon Foale

2004 Global Imperatives and Local Desires: Competing Economic and Environmental Interests in Melanesian Communities. In Pacific Island Societies in a Global World, edited by Victoria Lockwood, I49-I64. New York: Prentice Hall.

MMSD, Mining, Minerals and Sustainable Development Project

2002 Breaking New Ground: Mining, Minerals and Sustainable Development. London: International Institute for Environment and Development. 
PNG Post-Courier (Port Moresby)

2005a Demand for Skilled PNG Workers. Io October.

2005b Bougainville “No Go" for Mining. 5 October.

PNGdom, Papua New Guinea Department of Mining

2003 Sustainable Development Policy and Sustainability Planning Framework for the Mining Sector in Papua New Guinea: Green Paper. Port Moresby: PNGDOM.

Simpson, Gary

2002 Sustainable Development Policy and Sustainability Planning Framework for the Mining Sector in Papua New Guinea. Working Paper 6: Institutional Analysis. Port Moresby: PNG Mining Sector Institutional Strengthening Project.

Stürzenhofecker, Gabriele

I994 Visions of Landscape: Duna Pre-Meditations on Ecological Change. Canberra Anthropology I7 (2): 27-47.

Weiner, James, and Alan Rumsey, editors

200I From Myth to Minerals: Mining and Indigenous Lifeworlds in Australia and Papua New Guinea. Bathurst, Nsw: Crawford House Press.

West, Richard

I992 Development Forum and Benefit Package: A Papua New Guinea Initiative. Working Paper I6. Port Moresby: Institute of National Affairs.

\section{Abstract}

This introduction contextualizes the discussion of community responses to mining in Melanesia by looking first at the policies of minerals extraction and the shift of academic interest from economic development to the social effects of mining. As this collection concentrates on Papua New Guinea, an analysis of the sector and its problems in that country is briefly contrasted with the situation in other Pacific Island nations, canvassing the idea that the economic "resource curse" might have a social dimension. The varying interpretations of local impact and anthropological studies have challenged notions of unified interest or consensus at the local level, revealing ambivalence and contradictions. An overview of the contributions made in this special issue to current debates about stakeholder interests and economic sustainability is presented, showing that understandings of mining and its social consequences at each stage of the process are always inflected by the cultural conceptions of change, wealth, and resources that obtain in a community.

KEYwords: mining, Melanesia, Papua New Guinea, minerals policy, social change 